1881. March 29. The lad was readmitted, having suffered more, and lost flesh considerably. His temperature was very heetic. In April Mr. Barwell sounded through the persistent sinus, and detected a stone.

May 5. Leave for further procedure was obtained. 'The difficulties foreseen were trom proximity of twelfth rib to the erest of the ilium, and from anount of dense cicatricial tissue. l'atient, when etherizcd, was laid across a thick stundbag, so as to bend spine forwards and to the right. Mr. B. made the usual oblique incision, but the scar-tissne so obscured parts he could not trust them as guides to the kidney. He followed the sinus with his finger, detected the stone, and, passing the knife along the digit, laid the gland bare, obtaining more room by running the scalpel along lower border of last rib. An attempt to remove the stone failed, but produced some blecking, restrained by pressure, while he quiekly chucleated the land body enough to pass a silk ligature over it, and tic it near its cillyx ; bleeding being thus checked, the rest was more earefully peeled away, until he could feel the perlicle isolated and distinet. A second cord was passed in the same wat in firont of the kidncy, and tied round the pedicle en masse. There was not room to remove the organ entire. He cut it in two with scissors in the dlepth of the wound, severed each portion from the tied stalk, and remored them separately.

The boy's temperature after the first nighlt sfeadily improved. A good deal

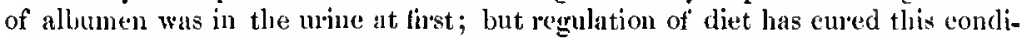
tion. A piece of sloughed ureter $4 \frac{1}{2}$ inche's long, with the ligutures attacherl, cune away on the forty-sixth day.

June 22. 'l'le boy is well in health. Has gained flesh. Temperature normal. Only a minute wound remains.

\title{
Partial Excision of the Bladder.
}

Dr. Adolph Fiscinfe, of Budal Pesth, presented a paper on this subject at the Lonlon Congress, which embraced the results of some interesting experimental cbservations. In order to answer on the gronnd of practical experience the following gnestions, he has excised larger or smaller portions firom the blatder of seren dogs.

1. Is it necessary in operating on dogs to take strict antiseptic precautions?

2. Is the operation attended by great dangers, and has the wound of the blatder, if properly stitched, a te'udency to heal?

3. Which material, and which kincl of suture is the most suitable?

Four of the seven doges recovered.

The first two were operaterl upon antiseptically; one died. I'ost-mortem.Sutnres not aceurate; peritonitis.

The sccond two not strictly antiseptieally; one died on the third day with a high temperature. Post-mortem.-Hemorrhage into the peritonesl cavity.

Three dogs operaterl upon not antisepticenlly at all ; one dierl. In the fatal ease Dr. Fischer had excised a considerable part fiom the trigonum resiew. Post-mortem.—Gingrene of the blukler.

T'he material for sutures was Lister's antiseptie silk, silk boiled in five per cent. earbolic lotion, and catgut. Each of these materials answered well. Dr. Fischer used the interrupted and the combined suture, and at modification of my own, the eombined interrupted suture.

From these experinents the following deductions may bc drawn :-

1. In operating on dogs antiseptic precautions are not absolutely necessary.

2. Wounds in the bladter, which arc afterwards carefully united by sutures, are not particnlarly dangerons.

3. Good results are principally dependent upon the aecuracy of the suture. 
There can be no doubt that this operation is more likely to be successful on the human subject, beeause it can be done antiseptically; the bladder can be subjected to a inechanical treatment (irrigation with antiseptic fluids); a eatheter can be kept in the bladrler, and absolute rest can be secmed.

The indieations for partial excision of the human bladder may be brought at present under the following lieals :-

1. Traumatic injuries to the hladder with contused edges.

2. Diverticula of the bladder, containing encysted calculi.

3. General dilatation of the bladder, when the cause of the disease lat either been removed or is removable.

4. Benign and malignant tumours involving the wall of the bladder.

5. Vesico-abdominal, resico-raginal, and recto-resical fistula.

6. Destructive ulcerations threatening ruptme, and withstanding other methorls of treatment.

\section{Treatment of Scrofulous Inflammation of Joints.}

Prof. Hueter real a paper at the London Congress on this subject, of which the following is an abstract:-

1. Scrofulous inflammation of a joint is characterized by the formation of granulation tissue, so that suppuration follows, - while in other forms of joint inflanumation, especially the tramnatic form, suppuration precedes, this formation of granulation tissue.

2. Scrofulous inflammation can be described as leading to the formation of granulations, as a synovitis granulosa, if jt proceeds from the synovial membrane; as at myelitis granulosa, if glamulation masses anc previously formed in the medullary substauce of the boues (of the joint). In the latter case, the sy'novitis granulosa follows the myelitis gramulosi.

3. In the scrofulous granulations, "noxa" develop themselves, which, at the seat of the prinury disease, lead to the formation of tubereles (local tuberculosis of joints), und by getting into the bloodressels, produce general tuberculosis (lungs, and other organs).

4. This form of joint-inftannnation may, therefore, be called the scrofulotubercular.

5. That form of joint.inflammation, which is produced by congenital syphilis, shows similar alplearances; it must, nevertheless, be differentiated, both for diagnostic and prognostic purposes, since there are no " nosæ" which can leal to tuberculosis.

6. The cally stage of scrofulons inflammation may be successfully treaterl by the injection of a $3-5$ per cent. solution of carbolic acid. The injection must be made with a Pravaz syringe, in such a way that the solution cones in immediate contact with the granulation tissue, $i . e$, with the interior of the joint, if the case is one of synovitis granulosa, and with the interior of the bone, if it be one of myelitis granulosa.

7. Antiphlogistic treatment of scrofulous joints (fixation, massage, compression, permancht extension, blool-letting, blistering), is of little or no value.

8. Incision into the joints, drainage, scraping away the gramulations, or partial venesection of a joint, are to be discarded.

9. Carbolic injections having fitilerl, excision is the best treatment, especially after suppuration has sct in.

10 and 11. Excision sloould be total. When practised early, the results are the most satisfactory. 